\title{
Clove oil as anaesthetic for juveniles of matrinxã Brycon cephalus (Gunther, 1869)
}

\author{
Óleo de cravo como anestésico para juvenis de matrinxã Brycon cephalus (Gunther, 1869)
}

\author{
Luis Antônio Kioshi Aoki Inoue ${ }^{1}$ Cristiano dos Santos Neto ${ }^{2}$ Gilberto Moraes $^{3}$
}

\section{ABSTRACT}

Many chemicals have been used as anaesthetics in fish farms and fish biology laboratories to keep the fish immobilized during handling procedures and to prevent accidents and animal stress. In Brazil, tricaine methane sulfonate (MS 222), quinaldine sulfate, benzocaine, and phenoxyethanol are the most common fish anaesthetics used to prevent fish stress during handling, but many side effects such as body and gill irritations, corneal damage and general risks of intoxication have been reported. Clove oil is a natural product proposed as an alternative fish anaesthetic by many researchers and it has been used in many countries with great economic advantages and no apparent toxic properties. In this work, we assessed the suitability of clove oil to anaesthetize matrinxã. Sixty-three juveniles of matrinxã were exposed to seven anaesthetic batches of clove oil (pharmaceutical grade) namely $18,20,30,40,50,60$, and $70 \mathrm{mg} / \mathrm{L}$. The times to reach total loss of equilibrium and to recover the upright position were measured. Clove oil concentration about $40 \mathrm{mg} / \mathrm{L}$ was enough to anaesthetize the fish in approximately one minute and the recovery time was independent in regard to anaesthetic concentration.

Key words: clove oil, anaesthetic, matrinxã.

\section{RESUMO}

Diversos produtos químicos têm sido empregados como anestésicos para peixes nas estações de piscicultura e laboratórios de biologia de peixes para a devida imobilização dos organismos, afim de se prevenir acidentes e ferimentos na superfície do corpo dos próprios peixes, que podem ficar susceptiveis a patógenos e taxas altas de mortalidade. A tricaina metano sulfonato (MS 222), a quinaldina, a benzocaina e o phenoxyethanol têm sido amplamente utilizados no Brasil, mas alguns efeitos colaterais são observados como perda de muco, irritação nas brânquias e olhos, e também alguns incômodos aos trabalhadores como a necessidade do uso de luvas. Dessa forma, o óleo de cravo é proposto como um anestésico alternativo por ser um produto natural de custo acessivel e sem riscos aparentes de intoxicações. No presente trabalho estudamos a possibilidade do uso do óleo de cravo como anestésico para juvenis de matrinxã, utilizando-se 63 peixes, expondo-os a banhos anestésicos nas concentrações de 18, 20, 30, 40, 50, 60 e $60 \mathrm{mg} / \mathrm{L}$, de forma que foram mensurados os tempos necessários para que os peixes atingissem a perda total de equilibrio e a incapacidade de retornar a posição normal de nado. A concentração de $40 \mathrm{mg} / \mathrm{L}$ foi suficiente para anestesiar juvenis de matrinxã em aproximadamente 1 minuto, sendo a recuperação independente da concentração do anestésico.

Palavras-chave: óleo de cravo, anestésico, matrinxã.

\section{INTRODUCTION}

Anaesthetics are often used in fish farms and fish biology facilities as a way to minimize fish hyper-motility, which is a considerable source of injuries during handling procedures and/or transport. The consequent damages from such accidents succumb fish to increase the susceptibility to pathogens and infection diseases. Therefore, reducing fish motility by anaesthetics may decrease the undesirable handling consequences.

${ }^{1}$ Engenheiro Agrônomo, Mestre em Aqüicultura, Bolsista CNPq (Processo 141595/01-9), Doutorando no Programa de Pós-graduação em Genética e Evolução, Universidade Federal de São Carlos.

${ }^{2}$ Doutor em Ciências, Professor Adjunto do Departamento de Ecologia e Biologia Evolutiva, Universidade Federal de São Carlos.

${ }^{3}$ Doutor em Ciências, Professor Adjunto do Departamento de Genética e Evolução, Universidade Federal de São Carlos, CP 676, 13565905, São Carlos, SP, Brasil. Telephone +55-16-2608376, Fax +55-16-2608377, E mail: gil@power.ufscar.br Corresponding author. 
The stages of anesthesia are associated to behavioral changes and loss of equilibrium and movements (IWAMA \& ACKERMAN, 1994; ROUBACH \& GOMES, 2001; WOODY et al., 2001). Anesthesia is reached when a complete or partial loss of body sensation due to depression of nervous functions is observed (IWAMA \& ACKERMAN, 1994).

The choice of an anaesthetic is usually both related to the economic viability and legal considerations (IWAMA \& ACKERMAN, 1994). Chemicals such as tricaine methane sulfonate (MS 222), quinaldine sulfate, benzocaine and phenoxyethanol are widely used to anaesthetize fish. However, many inconveniences such as loss of mucus, gill irritation and corneal damages can be observed.

In this way clove oil is pointed out as a potential fish anaesthetic alternative (WOODY et al., 2001). This oily substance is distilled from the extract of Caryophyllus aromaticus, a native tree from Asia and adapted to South America. The main chemical content of the clove oil is eugenol (70 to 98\%) (VELOZO, 2002). Eugenol or 4-allyl-2methoxyphenol $\left(\mathrm{C}_{10} \mathrm{H}_{12} \mathrm{O}_{2}\right)$ has multiple uses mainly in dentistry and medicine as an antiseptic, analgesic and anaesthetic agent (NATIONAL TOXICOLOGY PROGRAM, 2002).

Clove oil has been used as fish anesthetic in many countries with economic advantages and no apparent toxic properties (SOTO \& BURHANUDDIN, 1995; MUNDAY \& WILSON, 1997; SLADY et al., 2001; WOODY et al., 2001). However, data reporting ideal concentrations of clove oil to induce tropical fishes anesthesia are scarce.

We assayed the potential of alcoholic solutions of clove oil to anaesthetize matrinxã Brycon cephalus (Gunther, 1869) in the course of handling. Matrinxã is among the most important neotropical teleost fish, largely reared in Brazil under several rearing and feeding conditions due to the excellent growth (CYRINO et al., 1986). In this work, juveniles of matrinxã were anaesthetized with clove oil to assess the ideal concentration to induce anesthesia in Brycon cephalus.

\section{MATERIAL AND METHODS}

\section{General conditions}

Juveniles of matrinxã were supplied by a commercial fish farm located in Conchal, SP, Brazil. Experiments were carried out in the Adaptive
Biochemistry Laboratory facilities in the Federal University of São Carlos, SP, Brazil.

Fish were initially acclimated in circular fiberglass tanks (2000L) in an enclosed system of water used for 10 days. Physical and chemical parameters were weekly monitored and the average values were observed: $\mathrm{pH} 6.8$, temperature $25.7 \pm$ $0.9^{\circ} \mathrm{C}, \mathrm{pO}_{2} 5.66 \pm 0.07 \mathrm{mg} / \mathrm{L}$, water conductivity 74.3 $\pm 4.8 \mu \mathrm{S} . \mathrm{cm}^{-3}$.

\section{Experimental design}

Three 4L glass-aquaria were used as batches of freshwater plus clove oil to induce anesthesia. Sixty-three juveniles of matrinxã were used, and three fish per aquarium were anaesthetized, one after the other, and the time in seconds to reach the stage 3 of anesthesia (WOODY et al., 2001) was registered. Stage 3 of anesthesia in fish is observed when fish completely lose the equilibrium, and they are unable to regain the upright position. Seven concentrations of clove oil pharmaceutical grade were assayed: 18, 20, 30, 40, 50, 60 and $70 \mathrm{mg} / \mathrm{L}$. The hydrophobic trait of clove oil does not allow using it directly in the water. Hence, it was first diluted in Ethanol (one part clove oil: 20 ethanol) and a stock solution was made before the experimental batches. The assays were performed from the lowest to the highest concentration to ensure no residual effects from the glass adsorption. Aeration was provided in the course of the experiments, and physical and chemical water conditions were the same of the acclimation tanks. To emulate the field procedures, handling was carried out under anesthesia and the body weight $(\mathrm{g})$ and length $(\mathrm{cm})$ of specimens were measured.

Recovery was held transferring fish to 2,000L circular tanks provided with eugenol-free water and fish were assumed as recovered (stage III of recovery) when the equilibrium was reestablished and they started to swim horizontally (IWAMA \& ACKERMAN, 1994). Times to regain the upright position were also measured.

\section{RESULTS}

All fish exposed to the experimental concentrations of clove oil were anaesthetized reaching the stage 3 . Three distinct periods of anesthesia induction were observed in the range of the tested concentrations and the recovery time was independent of the anaesthetic concentration (Table 1).

Dose-effect curve of eugenol shows a tendency to a minimum period of anesthesia induction in concentrations above $40 \mathrm{mg} / \mathrm{L}$. The 
Table 1 - Induction time to anesthesia and body size of juveniles of matrinxã Brycon cephalus.

\begin{tabular}{lcccc}
\hline Clove oil & Induction time & Recovery time & Weight & Length \\
\hline 18 & $304.0 \pm 39.8 \mathrm{a}$ & $81.8 \pm 33.3$ & $51.4 \pm 8.5$ & $15.9 \pm 0.7$ \\
20 & $216.7 \pm 37.3 \mathrm{a}$ & $56.0 \pm 10.7$ & $49.2 \pm 4.5$ & $15.7 \pm 0.6$ \\
30 & $103.3 .0 \pm 18.6 \mathrm{~b}$ & $71.4 \pm 17.0$ & $48.0 \pm 6.2$ & $15.7 \pm 0.8$ \\
40 & $77.1 \pm 9.7 \mathrm{~b}$ & $58.1 \pm 11.4$ & $44.4 \pm 4.6$ & $14.9 \pm 0.6$ \\
50 & $75.6 \pm 5.6 \mathrm{~b}$ & $57.7 \pm 12.1$ & $51.0 \pm 9.1$ & $15.7 \pm 0.7$ \\
60 & $60.4 \pm 5.7 \mathrm{c}$ & $57.0 \pm 9.1$ & $46.6 \pm 4.4$ & $15.4 \pm 0.4$ \\
70 & $59.6 \pm 7.6 \mathrm{c}$ & $62.1 \pm 16.7$ & $46.1 \pm 6.2$ & $15.3 \pm 0.8$ \\
\hline
\end{tabular}

Clove oil is expressed in $\mathrm{mg} / \mathrm{L}$, time range of anesthesia and recovery in seconds, body weight in $\mathrm{g}$ and body length in cm. Same letters in the same column indicate similar values $(\mathrm{P}<0.05, \mathrm{~F}=134.32)$. Table values are expressed as Means \pm S.D.

reverse of induction time of anesthesia versus concentration of eugenol shows a sigmoid response (Figure 1). The reciprocal of the time interval $(1 / \Delta \mathrm{T})$ to reach the stage 3 of anesthesia is expressed in $1 /$ second. This profile suggests that the anaesthetic inhibits a pivotal molecule in a typical process of cooperative-response.

The mathematical arrangement of the data allowed to establish a way to predict the time to induce anesthesia in juveniles of matrinxã according to $\mathrm{I}=6893.7 \mathrm{x}[\mathrm{C}]^{-1.16277}$, where $\mathrm{I}$ is the

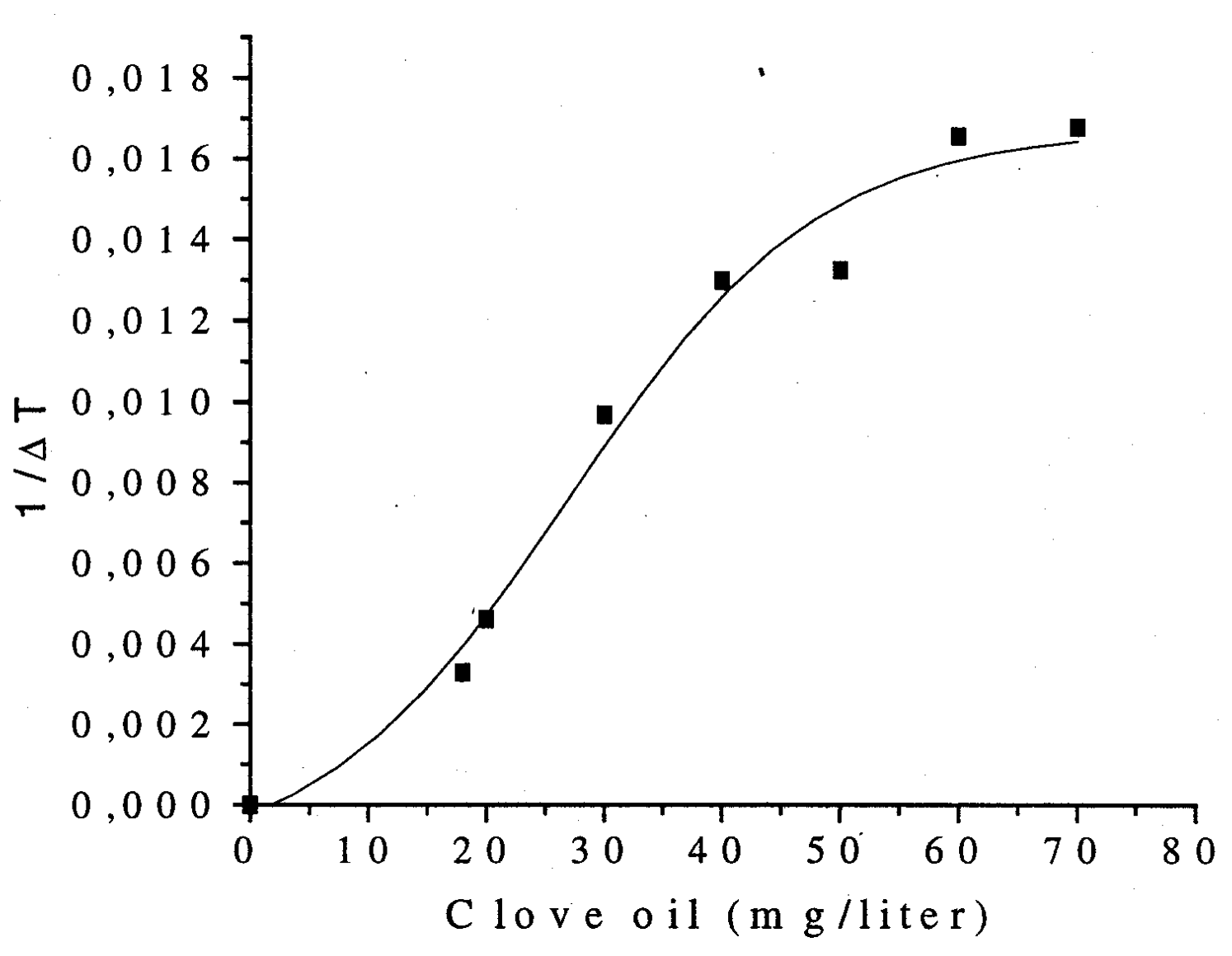

Figure 1 - Dose-effect curve of eugenol for juveniles of matrinxã Brycon cephalus.

The reciprocal of the time interval $(1 / \Delta \mathrm{T})$ to reach the stage 3 of anesthesia is expressed in $1 /$ second.

Ciência Rural, v. 33, n. 5, set-out 2003. 
induction time of anesthesia in seconds, and [C] is the clove oil concentration in $\mathrm{mg} / \mathrm{L}$ (Figure 2). Equation data are $\mathrm{R}$-square $=87.6 \%$ and $\mathrm{F}=429.636$ in anesthetic batches ranging from 18 to $70 \mathrm{mg} / \mathrm{L}$.

Fish weight $(\mathrm{g})$ and length $(\mathrm{cm})$ were easily measured suggesting the stage 3 of anesthesia was sufficient to routine procedures such as biometry. No fish mortality was observed due to clove oil exposure, and the animals were feeding as usual few hours later.

\section{DISCUSSION}

During handling procedures in fish farms and fish biology facilities, animals must be usually anaesthetized to reduce stress and to prevent the possibility of injuries. However, anaesthetics by themselves may stress fish (MUNDAY \& WILSON, 1997; SLADY et al., 2001; WOODY et al., 2001). Eugenol, the main component of clove oil, was reported to reduce the stress during transport and handling procedures in Anguilla anguilla (KUHLMANN et al., 2000). The use of clove oil as an alternative anaesthetic in the handling of matrinxã seems to be feasible and it is a promising agent to other fish species.

The physiological effect of eugenol is not clearly known but it has been suggested to interfere in the fish olfactory sense (WOOD et al., 2001) similarly to the reported effect of tricaine methane sulfonate (LEWIS et al., 1985).

The concentration of an anaesthetic to induce anesthesia may vary among the species, and within the same one, it does pursuant to the size (MUNDAY \& WILSON, 1997; SLADY et al., 2001; WOODY et al., 2001). Signatus lineatus showed a narrow range of time to lose consciousness in clove oils batches from 33 to $100 \mathrm{mg} / \mathrm{L}$ (SOTO \& BURHANUDDIN, 1995).

No evident damages were observed for juveniles of matrinxã when exposed to clove oil anaesthesia. However, further studies have been carried out to evaluate the metabolic effects of eugenol, and additional data are necessary in order to assess the toxicological effects on the reproduction and growth.

\section{CONCLUSION}

Clove oil is a potent fish anaesthetic to reach stage 3 of anesthesia within approximately one minute in safe concentrations ranging from 40 to $50 \mathrm{mg} / \mathrm{L}$.

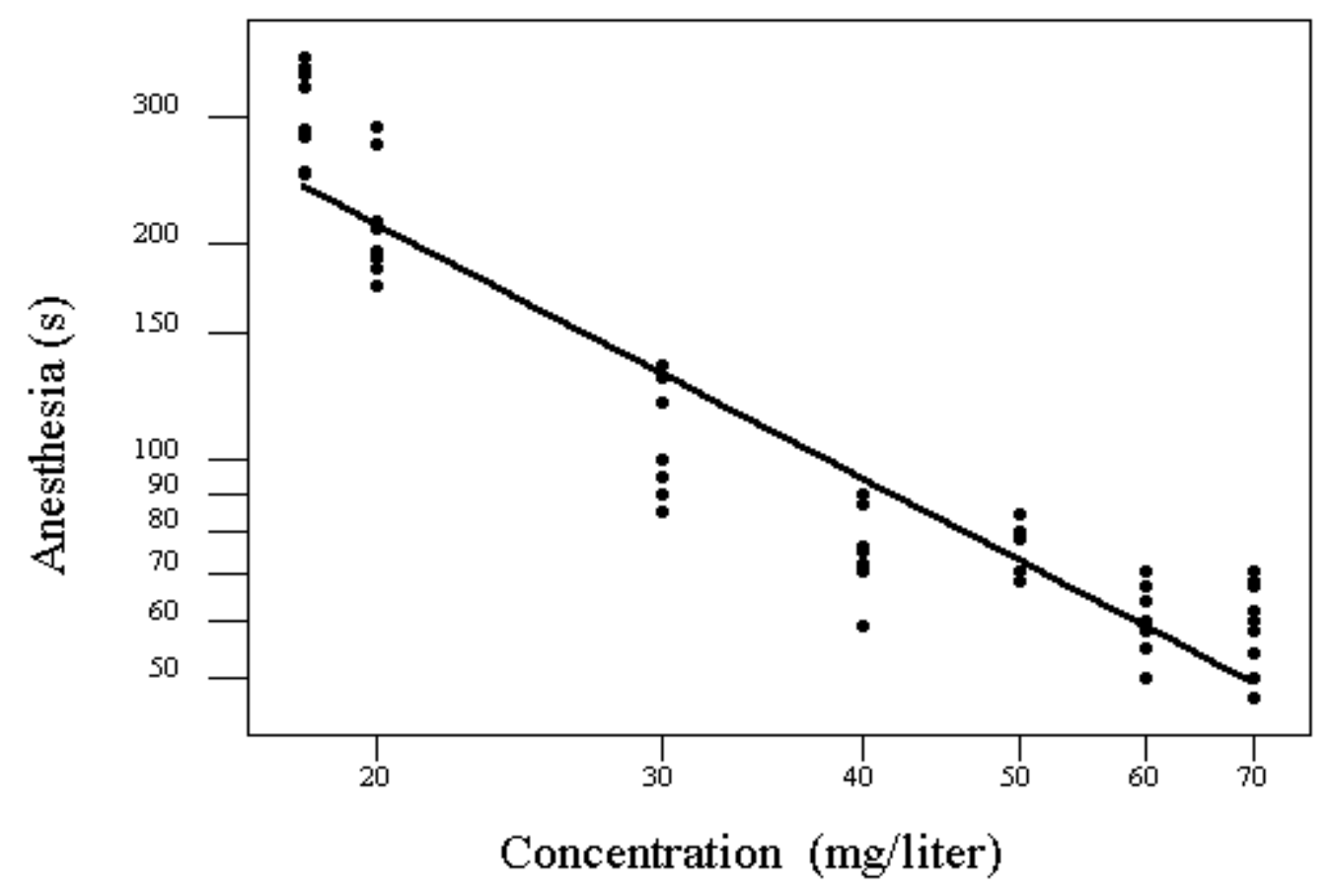

Figure 2 - Induction time of anesthesia in juveniles of matrinxã Brycon cephalus by clove oil added to the water.

Ciência Rural, v. 33, n. 5, set-out 2003. 


\section{ACKNOWLEDGEMENTS}

The authors thank to Galo Piscicultura (Conchal, SP, Brazil) and Piscicultura Águas Claras (Mococa, SP, Brazil) for providing the fish used in this research and in the previous studies.

\section{REFERENCES}

CYRINO, J.E.P.; CASTAGNOLLI, N.; PEREIRA-FILHO, M. Digestibilidade da proteína de origem animal e vegetal pelo matrinxã (Brycon cephalus GUNTHER, 1869) (Eusteiostei, Characiformes, Characidae). In: SIMPÓSIO BRASILEIRO DE AQUiCUlTURA, 4., 1986, Cuiabá. Anais... Cuiabá : Universidade Federal de Mato Grosso, Funep, 1986. p.4962.

IWAMA, G.; ACKERMAN, A. Anaesthetics. In. HOCHACHKA P.; MOMMSEN. Analytical techniques in biochemistry and molecular biology of fishes. Amsterdan : Elsevier Science, 1994. V.3, Cap.1, p.1-15.

KUHLMANN-H. et al. Investigations of anaesthetic effect of Eugenol ("Aqui-S") and similarly structured compounds on eel (Anguilla anguilla). Archiv-fur-Lebensmittelhygiene, v.51, n.3, p.60-62, 2000

LEWIS, D.H. et al. Drugs induced structural changes in olfactory organ of channel catfish Ictalurus punctatuts. Journal of Fish Biology, v.26, p.355-358, 1985.
MUNDAY, P.L.; WILSON, S.K. Comparative efficacy of clove oil and other chemicals in anaesthetization of Pomacentrus amboinesnsis, a coral reef fish. Journal of Fish Biology, v.51, p.931-938, 1997.

NATIONAL TOXICOLOGY PROGRAM. Clove oil. Capturado em 23 mai, 2002. Online. Disponível na Internet http://ntpserver.niehs.nih.gov/

ROUBACH, R.; GOMES, L. Uso de anestésicos durante o manejo de peixes. Panorama da Aquicultura, v.11, n.66, p.37-40, 2001.

SLADY, K. et al. Comparative efficacy of tricaine methanesulfonate and clove oil for use as anaesthetic in red pacu (Piaractus brachypomus). American Journal of Veterinary Research, v.62, n.3, p.337-342, 2001.

SOTO, C.; BURHANUDDIN. Clove oil as a fish anaesthetic for measuring length an weight of rabitfish (Siganus lineatus). Aquaculture, v.136, p.149-152, 1995.

VELOZO, E. Histoquímica do cravo. Universidade Federal da Bahia. Homepage. Capturado em 22 mar, 2002. Online. Disponível na Internet. http://www.ufba.br/ euvelozo/ monograf.htm

WOODY, C.A.; NELSON, J.; RAMSTAD, K. Clove oil as an anaesthetic for adult sockeye salmon: field trails. Journal of Fish Biology. Capturado em 20 mar, 2002. doi:10.1006 jfbi.2001.1842. Online. Disponível na Internet http:// www.idealibrary.com 